\title{
Web clearinghouse promotes displays of government information
}

Minnesota State University's (MSU) Memorial Library has created a Web-based clearinghouse of government documents displays at http://www.lib.mankato.msus.edu/lib/ govdoc/proj/tutorials/finalfront2.html.

The clearinghouse was developed by MSU's Mark McCullough, government documents/maps librarian; Mary Nere, government documents technician; and Pam Schmutz, reference librarian.

The clearinghouse is part of a larger tutorial on government documents displays, which is supported by an award from

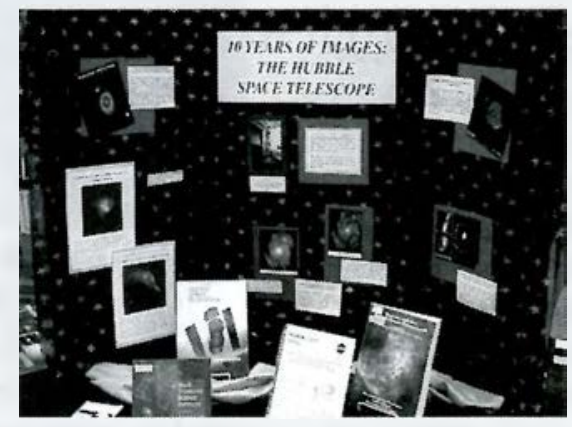

Instead of traveling to other libraries, library staff can visit the online clearinghouse to gather creative ideas.

While most submissions have come from U.S. federal depository libraries, the clearinghouse creators would like to expand the project by welcoming promotional displays that exhibit state, local, and international government documents. They are especially interested in receiving displays from libraries outside the United States.

Any library that has created promotional disthe ALA GODORT Continuing Education Committee. The clearinghouse features images, descriptions, and bibliographies of government documents displays created by libraries throughout the United States. Since its unveiling in April 2000, the clearinghouse has received more than 40 submissions from 18 libraries, including several virtual displays.

The clearinghouse displays vary from the simple tabletop variety to elaborate exhibits. Display titles include: "Ten Years of Images: The Hubble Space Telescope," "National Library Week," "History of the Internet," and "Biotechnology: The Genetics Revolution." The images and bibliographies are intended to make it easier and less time-consuming for library staff as they assemble displays in their own libraries. plays incorporating government information (tax forms, topographic maps, etc.) is invited to submit its display to the clearinghouse. The displays do not need to include only government documents, but they should include some. Displays are typically posted on the clearinghouse Web site within two weeks of submission, and contributors' names are added to the clearinghouse.

To submit your display to the clearinghouse, send electronic images and bibliographies to mark.mccullough@mankato.msus. edu. Photographs and disks can be mailed to Mark McCullough, Memorial Library, P.O. Box 8419, Minnesota State University, Mankato, Mankato, MN 56001,-Mark McCullough, Minnesota State University, Mankato, mark. mccullough@mankato.msus.edu

\section{Register for ACRL preconferences}

Keep up with the latest developments in licensing, instruction, information literacy, library-faculty collaboration, or rare books at one of ACRL's preconferences that will be offered in San Francisco, June 15, prior to the ALA Annual Conference:

- "Navigating the Licensing Landscape"

- "How to Keep From Glazing Over When You Hear the Word Assessment: Re- alistic Strategies for the Library Instruction Community" (Instruction Section)

- "Reaching Students and Faculty: Putting the Information Literacy Competency Standards to Work"

- RBMS Preconference: "The Twentieth Century," June 12-15, 2001

- "Creating Successful Librarian-Faculty Collaborations: The State of the Art." Registration details are on the Web at http://www.ala.org/acrl/confhp.html. 